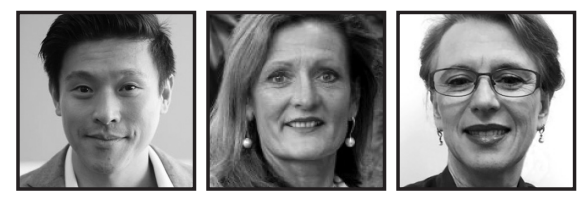

\title{
"Sowing and Growing" Life Skills Through Garden-Based Learning to Reengage Disengaged Youth
}

Son Truong, Tonia Gray, and Kumara Ward, Western Sydney University

\section{ABSTRACT}

There is an emerging body of literature that explores the impact of garden-based learning on health, well-being, social cohesion, and educational outcomes. In this paper, we examine a pilot study conducted in partnership with the Royal Botanic Gardens' Youth Community Greening to implement a gardening program with disengaged youth. Data was collected through fieldwork and semi-structured interviews, revealing five interconnected themes: enhancing well-being and health literacy; building life skills; engaging students; connecting with adults; and increasing selfesteem. We conclude by showcasing some of the collaborative practices between educational contexts and communities to reveal how these partnerships can be mutually enhancing.

\section{Background to the Study}

his study examines a collaborative partnership with the Royal Botanic
Gardens' (RBG) Youth Community Greening (YCG) to implement a garden-
based learning (GBL) program, called Outdoor Links To Learning (OL2L), with disengaged students. YCG is an environmental education program that targets youth (12-25 years) in disadvantaged communities by helping create productive schoolcommunity gardens. The innovative program delivers syllabus-linked environmental education and outdoor activities at schools and centres and has been found to be an effective way to engage students in learning: 
Before Peter [YCG Coordinator] came to our school, our environment club was only a name. Now with his valuable help and expertise, we have a vegetable garden up and running and the children take pride in their efforts. We have since grown many different vegetables, harvested, cooked and eaten the produce!! They enjoy this experience and can't wait for Fridays, which is our official 'Gardening Day' (School Feedback, YCG Annual Report, 2015).

\section{Collaborative Research Between Educational Contexts and Communities}

It is widely acknowledged that partnerships between educational contexts and communities can be mutually enhancing (Aftandilian \& Dart, 2013). Our research involves three key collaborators: Western Sydney University; RBG Community Greening Project Coordinators; and a public school suspension centre in South West Sydney who joined together to create and implement this OL2L program.

\section{The School Site}

The school is one of 22 suspension centres within the New South Wales (NSW) Department of Education and Communities (DEC). The program works with students on long suspension from schools in Sydney's South West to provide engaging learning and behavioral support that improve students' chances of success on their return to school. It operates under the auspices of a regionally located school principal, a head teacher, and a part-time special learning support officer, and specifically caters for students while they are on suspension from school.

The referral process to the suspension centre follows a distinct protocol. When a student is placed on long suspension, the school, parents, and/or community workers contact the head teacher at the centre to arrange an interview to assess the learning needs of the student. Based on the outcome of this meeting, an individual learning program is developed by the centre with additional information collected from the school after student participation is confirmed. Generally, students begin attending within one to two days after making initial contact. Students return to their schools after a resolution meeting with the parents has taken place.

The OL2L program builds on previous studies that show the importance of a connection to nature for health, well-being, and educational outcomes (Dickson, Gray, \& Mann, 2008; Gray \& Thomson, 2016; Passy, 2014; Passy, Morris, \& Reid, 2010). Using GBL approaches, the school-community program engages students in the process of designing, building, and maintaining a garden through to a point where 
produce is successfully harvested, cooked, and consumed. The program draws on the expertise of the YCG project, which shows that GBL has a positive impact on academic outcomes for students across the curriculum, and also on attitudes towards gardening, the environment, and nutrition. Emerging research shows that for at-risk students who participate in a GBL school program, the proportion of successful students increases, dropout and failures decrease, and there are improvements in attitudes toward school, self-esteem, and skill development (Ruiz-Gallardo, Verde, \& Valdés, 2013).

This paper examines the findings from this ongoing research project, which was first implemented in 2015. The following section focuses on the literature review, which frames the study in contemporary research in community gardening and greening, GBL, environmental education, and the nature-well-being connection. The subsequent section provides an overview of the research methodology and data collection methods employed in the project. Data analysis resulted in five central themes within the GBL program: 1) enhanced health literacy and well-being; 2 ) building life skills; 3 ) engaging students in alternative educational environments; 4) connecting with adults; and 5) increasing self-esteem and social connection. We conclude by showcasing some of the compelling stories and examples of innovative practice for engaging disengaged youth through GBL. Additionally, we seek to stimulate discussion on the development of collaborative practices between educational contexts and communities by exploring the implications of innovative pedagogy.

\section{Literature Review}

\section{Children With Challenging Behaviours in Our Education System}

The teaching context invariably affects student learning and engagement. Behavioral and emotional challenges, disconnection, and disengagement are issues that undermine academic excellence during schooling and need to be addressed for the benefit of all concerned. Against this backdrop, dealing with disconnected and vulnerable students is a complex challenge confronting 21st century educators (Deci, Koestner, Ryan, \& Cameron, 2001). Durlak, Dymnicki, Taylor, Weissberg, and Schellinger (2011) assert that students whose behaviour is labeled "at-risk," gives cause for concern to those charged with the responsibility of ameliorating the problem. Although written almost three decades ago, Nel Noddings' (1988) reflections are strikingly relevant today more than ever: 
At a time when the traditional structures of caring have deteriorated, schools must become places where teachers and students live together, talk with each other, take delight in each other's company. It is obvious that children will work harder and do things... for people they love and trust. (Noddings, 1988, as cited in Roffey, 2016, p. 39)

Our study connected community mentors, teachers and students through innovative GBL opportunities, in an attempt to foster restorative potentials for student engagement.

\section{Outdoor Learning as a Vehicle for Educational and Community Engagement}

The seminal work of Dr. Kurt Hahn in the post-WWII years was instrumental in shaping outdoor experiential learning as known today (Gray, 1997). In essence, he maintained that the traditional school curriculum was inadequate for the total development of the child (Ewald, 1970; Gray \& Perusco, 1993; Ryan \& Gray, 1993) and repeatedly emphasized the need for education to reach beyond the classroom and for students to find expression in the world at large. Hahn's educational thought suggested an adolescent's self-concept was developed through nature-based experiences (Kesselheim, 1974; Rohrs, 1970).

The emergence of the outdoor learning movement in western countries began as early as the 1940s and 1950s, in an attempt to counterbalance conventional methodologies employed in traditional classroom teachings. The "four-walled" delivery of educational messages is considered by many to be archaic and meaningless (Conrad \& Hedin, 1982; Knapp, 1992). In a similar vein, Horwood (1993) articulates "schooling is inordinately absorbed with information; information which was often dated, usually irrelevant to students and unavoidably ephemeral" (p. 46). Often, the traditional classroom does not relate in a dynamic way to the life a child feels in his or her body (Gray \& Birrell, 2015) and outdoor education is a potent vehicle for engaging students.

Benefits of outdoor learning. The positive influence of nature, green space, and outdoor activities on children and adolescents has been well researched (Africa, Logan, Mitchell, et al., 2014; Fägerstam, 2014; Selhub \& Logan, 2012; Wilson, 2015). Benefits include enhanced physical fitness, reduced obesity, the promotion of well-being, and lowering stress levels (Barton, Sandercock, Pretty, \& Wood, 2015; Dowdell, Gray, \& Malone, 2012; Gray \& Birrell, 2014; McCurdy, Winterbottom, Mehta, 
\& Roberts, 2010; Okely \& Gray, 1997; Sharma-Brymer \& Bland, 2016; Yeh et al., 2015). Outdoor learning has also been connected to enhanced self-esteem, mental health, and resilience (Chawla, Keena, Pevec, \& Stanley, 2014; Collado, Staats, \& Corraliza, 2013; Flouri, Midouhas, \& Joshi, 2014), and also improving environmental awareness (Chawla, 2007; Cheng \& Monroe, 2012; Ewert, 2004). Additionally, experiential outdoor education builds social capital through interpersonal and intrapersonal skills whilst also heightening mental acuity and concentration (Beames \& Atencio, 2008; Harun \& Salamuddin, 2014; Korpela, Borodulin, Neuvonen, Paronen, \& Tyväinen, 2014; Propst \& Koesler, 1998; Taylor \& Kuo, 2009; Taylor, Kuo, \& Sullivan, 2002).

Motivational factors linked to outdoor learning and GBL. Motivational factors have a profound influence on students' participation in educational experiences, particularly those conducted in an outdoor environment (Quay, 2015). The forefather of outdoor education, Kurt Hahn (cited by Gray, 1997) repeatedly emphasized that young people will take pleasure in learning if the environment is attractive and the lessons are both interesting and worthwhile.

Compelling evidence demonstrates the beneficial effects of natural environments to facilitate learning and provide experiences that are enriching and indelible (Davies, 1993; Gray \& Martin, 2012; Ward, 2016; Truong, 2009; Truong \& Mahon, 2012). Young people face many challenges framing their future, including building their sense of identity as they interact with, and encounter, a changing world. They experience peer pressure and have to deal with increasingly complex social and emotional issues. Collectively, these factors may contribute towards students becoming disconnected with their schooling or at-risk of not completing their studies. The OL2L program engages with these students through a GBL approach, which defined broadly, is "an instructional strategy that utilizes a garden as a teaching tool" (Desmond, Grieshop, \& Subramaniam, 2004, p. 9). In essence, GBL connects at-risk students to a teaching philosophy that emphasizes a human-nature partnership-connection with self, others, and the natural world.

A recent research report from Harvard's School of Public Health "Natural Environments Initiative" (Africa, Logan, Mitchell, et al., 2014) states:

Although it is a poetic truism to say that a garden can live on in one's heart forever, experience with gardening programs in youth is associated with pro-environmental attitudes later in life. Preliminary studies also suggest that gardening experience in school settings increases positive environmental attitudes and subsequently increases the value placed on local foods, including the environment in which 
produce is grown. This finding is consistent with studies that indicate early experiences in nature influence subsequent environmental attitudes and concern for stewardship and sustainability. (p. 19)

Readily influenced by their environment, a young person's personal development is shaped by their relationships with family, friends, school, and community. Disengagement from family, school, and social structures can result in a loss of social pathways to the learning of life skills and cognitive development. Young people are also affected by their surroundings - the built and natural environment-but many young people today are growing up with fewer opportunities to connect with nature and find inspiration from the appreciation and conservation of the environment.

Level playing field: Mentors rather than teachers. The increased likelihood of adult mentors being able to positively influence at-risk adolescents' attitudes, values, and behaviours has been well documented (Jackson, 2002; Rhodes, Grossman, \& Resch, 2000; Roffey, 2016). These interventions can avert the twofold burden on society by specifically identifying anti-social behaviours and influencing positive transition before progressing onto future adult life (Brand, 2001; Brand \& Smith, 1999; 2000; Handley, 1998). Similarly, the quality of the relationship between student and teacher is integral to productivity and engagement (McLoughlin \& Clarke, 2010). Consequently, learning outdoors is also an emerging field of research and pedagogy (Scott, Boyd, \& Colquhoun, 2013), especially when collaboration between educational contexts and community mentors can be seen to augment learning.

\section{Methodology}

\section{Conceptual Framework}

An interpretivist, inductive approach underpins this research with the qualitative methodology including observation, in-situ discussion, and semi-structured interviews. Analysis was conducted using thematic coding, through identifying similarities and differences across the data to identify common themes. Analysis software, NVivo, was used for the transcribed and text data sources and an iterative interpretive process for the development of themes (Weed, 2005). Reconsideration of taken-forgranted assumptions is a feature of the interpretive approach (Eisenhart, 1998) and cross-referencing of data across data sources and coders amongst the research team helped to infer and consolidate meaning. 


\section{Methods and Design}

GBL focuses on the development of life and employment skills, through outdoor learning activities, including gardening, horticulture, bush tucker, and cooking. This approach to teaching creates unique interdisciplinary/cross-curricular links with Australian Curriculum learning areas, namely English, Mathematics, Science, Humanities and Social Sciences, The Arts, and Health and Physical Education. For example, the design and construction of the garden beds engaged the students in arts and applied mathematics and the planting, nurturing, harvesting, and cooking of the plants engaged them in natural sciences. Life skills were also featured towards the harvesting end of the cycle and the negotiation, communication, and development of awareness of food resources brought connections to English, humanities, and eco-justice issues in the social sciences.

OL2L operated for two terms during 2015 (Terms 2 and 3) for 10 weeks in each term. Students attended for varied periods of time depending on their attendance at the suspension centre. Over the course of the two terms, up to 18 upper primary and 30 high school students attended from six primary and 12 high schools. Impact evaluation of the program involved a variety of data collection methods before, during, and after program implementation with students and teachers.

Evaluation included monitoring student attendance and academic performance while at the suspension centre, and observations of engagement throughout each term. Data collection involved participant observations, in-situ discussions, and semi-structured interviews with the community educators, teachers, and students. This information was used not only to refine the content and delivery of the program, but also to inform school-community pedagogical practice and to enhance student engagement.

\section{Findings}

The OL2L program has shown how a synergy between school and community can become a mutually reinforcing partnership. Learning can be augmented by extending the four walls of the traditional classroom, and by reaching into the broader community for mentoring expertise. This notion opens a landscape of possibilities that was shown to be reciprocally beneficial and enhanced learning. The findings from this research are considered under the five interrelated themes: 1) enhancing health literacy and well-being; 2) building life skills; 3 ) engaging students in alternative educational environments; 4) connecting with adults; and 5) increasing self-esteem and connection for participants. Figure 1 provides a conceptual model for discussing the findings. 


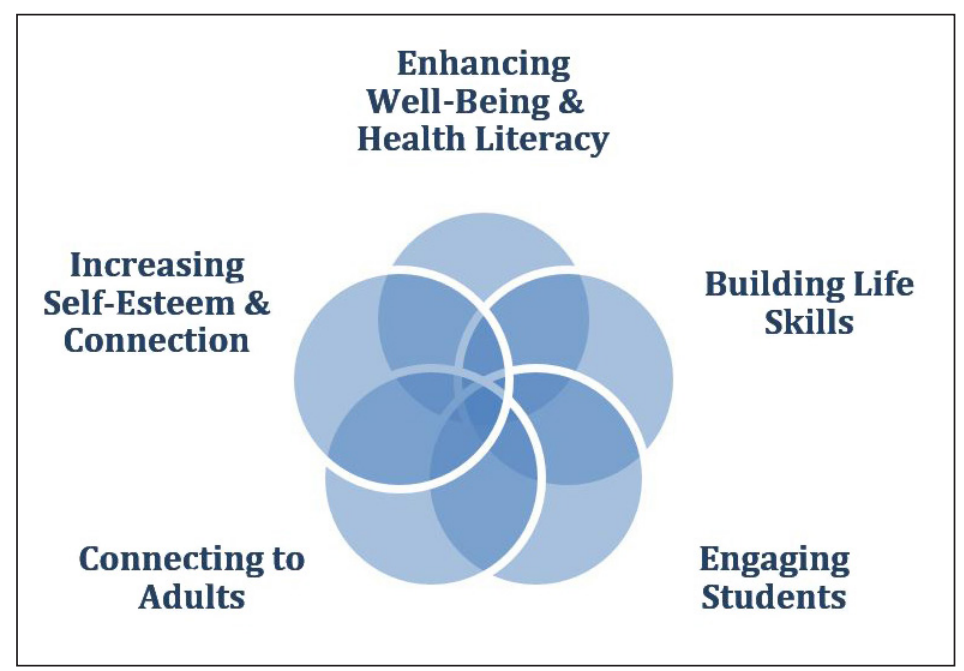

Fig. 1: Impact of OL2L program on learning and engagement

\section{Enhancing health literacy and well-being}

I made a couple of [garden] beds, other vegetable beds and so we put tomatoes, lettuce, radish, cucumbers, and strawberries, I think. When it gets pretty big, last time I was here we had a barbecue. We made patties with-so we made hamburgers with lettuce, tomatoes, radish, and some nice herbs we got from the herb garden. I cooked on the barbecue; made the patties. (Aaron, OL2L student)

In this narrative, Aaron recounts his experiential learning through the GBL program, which provided him with an opportunity to develop knowledge about growing fresh food, positive attitudes towards healthy eating, as well as hands-on cooking skills. Similarly, all students engaged in the program gained knowledge of planting and growing fresh produce, composting, and caring for the natural environment. Our findings suggest that GBL promotes the development of health literacy amongst students, particularly in relation to the consumption of fresh produce and supporting environmental health. This learning was enabled through the facilitation of the GBL educators, who were able to integrate discussions on fresh food and healthy eating into their informal interactions with the students.

In a discussion paper, Kanj and Mitic (2009) explain how the concept of health literacy builds upon traditional understandings of linguistic literacy. Extending from this, health literacy is an emerging concept that is characterized as, "The degree to which people are able to access, understand, appraise and communicate information 
to engage with the demands of different health contexts in order to promote and maintain good health across the life-course" (Kwan, Frankish, \& Rootman, 2006, p. 80).

Within this study, we found that the short-term impact of growing fruits, herbs, and vegetables with students included enhanced awareness of healthy eating and increased enjoyment of eating fresh food. This is in line with research that indicates garden-based nutrition education improves students' eating habits and consumption of fresh fruits and vegetables, while also providing an engaging form of physical activity (DiClaudio, Hughes, \& Savoca, 2013). What stood out the most for one of our GBL educators was the extent to which the students commented on their enjoyment of fresh food. In an interview, Peter affirmed:

The thing that I was struggling with the most was the comments from some of, particularly the younger kids about how much they enjoyed the fresh food and how they really loved eating fresh food, which made me think they probably don't do it very often, but they would really like to if they were given that opportunity. So, that was really positive on one hand, but also concerning on the other. (Peter, YCG Coordinator)

In this statement, Peter highlights one of the unique contributions of $\mathrm{GBL}$, which provides students with experience-based learning in nature. The educators and researchers observed that the program led students to develop a deeper appreciation for growing, cooking, and producing fresh food. In addition to supporting the development of health literacy, GBL provides an alternative learning environment, the natural world, which has been shown to enhance a sense of well-being. The recently published NSW Department of Education and Communities' (NSW DEC, 2015) Wellbeing Framework for Schools, emphasizes the importance of student well-being in learning and development:

Wellbeing, or the lack of it, can affect a student's engagement and success in learning. Educators need to understand the potential wellbeing has to bring about positive change, what is required to foster wellbeing, and how it can become a powerful force in students' learning and development. (p. 2)

Fraillon (2004) states, "wellbeing is the degree to which a student is functioning effectively in the school community" (p. 6). The NSW DEC (2015) further elucidates that common characteristics found in definitions of well-being include: positive attitude, resilience, sense of satisfaction, and overall quality of life across cognitive, emotional, social, physical, and spiritual domains. The following themes provide further support for GBL as a means to enhancing student engagement 
and well-being and highlight the need for continuing research to examine the impact of GBL over time.

\section{Building life skills}

The experiential nature of the GBL teaching and learning approach is captured in the following field notes from Peter, one of the educators who led a group of five students from the suspension centre on an outdoor clean-up day. Reflecting on the experience, he shared how one of the students excitedly told him that the carrots in the school garden had germinated, followed by participation in outdoor learning activities:

Guys from a restoration company talked a little about the plants in the area, then we split into five teams for a bush relay. Each team was given the description of a weed with a couple of photos and we had to run into the bush and get a sample. The kids completed and competed very enthusiastically... Once the first one was found they were given another sheet and this was repeated for three weeds and three natives and we won...

They did very well and even those slightly less enthusiastic at the start got into it.

The lunch wasn't quite ready so [we] took them for a walk through the bush where I got them to eat a bit of wattle sap and we had the chance to have a bit of a chat. Once back, we ate and it was then time for them to be picked up. (Peter, YCG Coordinator)

These field notes summarize the positive interactions, informal learning, and focus on life skills that took place through this project. There were certainly the more overt learning outcomes, such as seeing the carrots had germinated, and learning about the weeds and the native flora, but there were also all the learning opportunities that emerged through the process itself: the communication and informal social interaction the students have with an adult; the teamwork, cooperation, and even competition of the bush relay; and lastly the tasting of the wattle sap and the informal discussion about bush tucker and food. Throughout that day, the students were learning about and developing important life skills, without being told that this was happening.

While there is no single definition of life skills, they are generally viewed as personal management and social skills that are required for an individual to function in society (Singh, 2003). UNICEF (2003) defines life skills as "psychosocial abilities for adaptive and positive behaviour that enable individuals to deal effectively with the demands and challenges of everyday life" (para. 3). If we interrogate this a little deeper, we can consider three broad categories of skills: cognitive, personal, and interpersonal 
(UNICEF, 2003). Through a hands-on experiential approach, the students developed their cognitive skills, as evidenced through problem-solving and analyzing information given to them for constructing the garden beds, herb spiral, and compost bins. The development of personal skills to support a sense of agency and managing one's behaviour was not only observed by the research team, but also reported by the Head Teacher, who knew these students well and reported remarkable differences in their classroom behaviour versus their conduct while outdoors in the garden. Their ability to be self-directed, stay on task, and persevere was demonstrated in a variety of ways while learning in the garden space. Lastly, the students' cooperation on the clean-up day, was just one example of their positive interactions with one another. Students of varying ages and backgrounds were able to work together in the garden, support one another to accomplish specific tasks, and also teach each other new skills and knowledge within the GBL context.

\section{Alternative environments and behavioural change}

Watching the students at the suspension centre brings Erin Kenney's (2013) often used quote to mind: "Children cannot bounce off the walls if we take away the walls." Although the space in which the gardens were constructed was not much bigger than a suburban backyard, there were no walls nor doors to form metaphorical or physical barriers and no evidence of student/teacher positions of power or status by way of room and furniture arrangements (Guardino \& Fullerton, 2010). The students attending the suspension centre come from low resourced communities and, consistent with Astell-Burt, Feng, Mavoa, Badland, and Giles-Corti's (2014) findings, are likely to have fewer experiences with green spaces. Taking the learning environment outdoors is a new experience for them and the following quote suggests it is one the students are keen to participate in.

Whether it was because they were keen to get outside and make sure no-one was unhappy, I don't know, or whether it was making them think about that and wanting to get through it quick so they could get out, I don't know. That's got to be a good thing if in a general school sense with kids that are at risk of being suspended perhaps, if you can include that in their day for them, gardening, and that gives them an incentive to work, then I think it has got to be a good thing... in terms of a learning tool. (Phil, RBG Community Greening Project Coordinator)

There are potentially many reasons for the students' enthusiasm, but key among them is the variety of ways to engage in the outdoor space. The GBL program provided opportunities for physical activity with the shoveling of soil and gravel and in building, planting, and tending to the gardens. Vegetable garden beds were 
constructed using timber (see Figure 2) and a spiral herb garden was made using besser blocks (see Figure 3). Throughout the experience-based process, students learned about the qualities and uses of timber, and the unique considerations for growing a variety of vegetables. The learning was contextualized and made relevant for students. For example, they learned about water flows and micro-climates while creating the herb spiral.

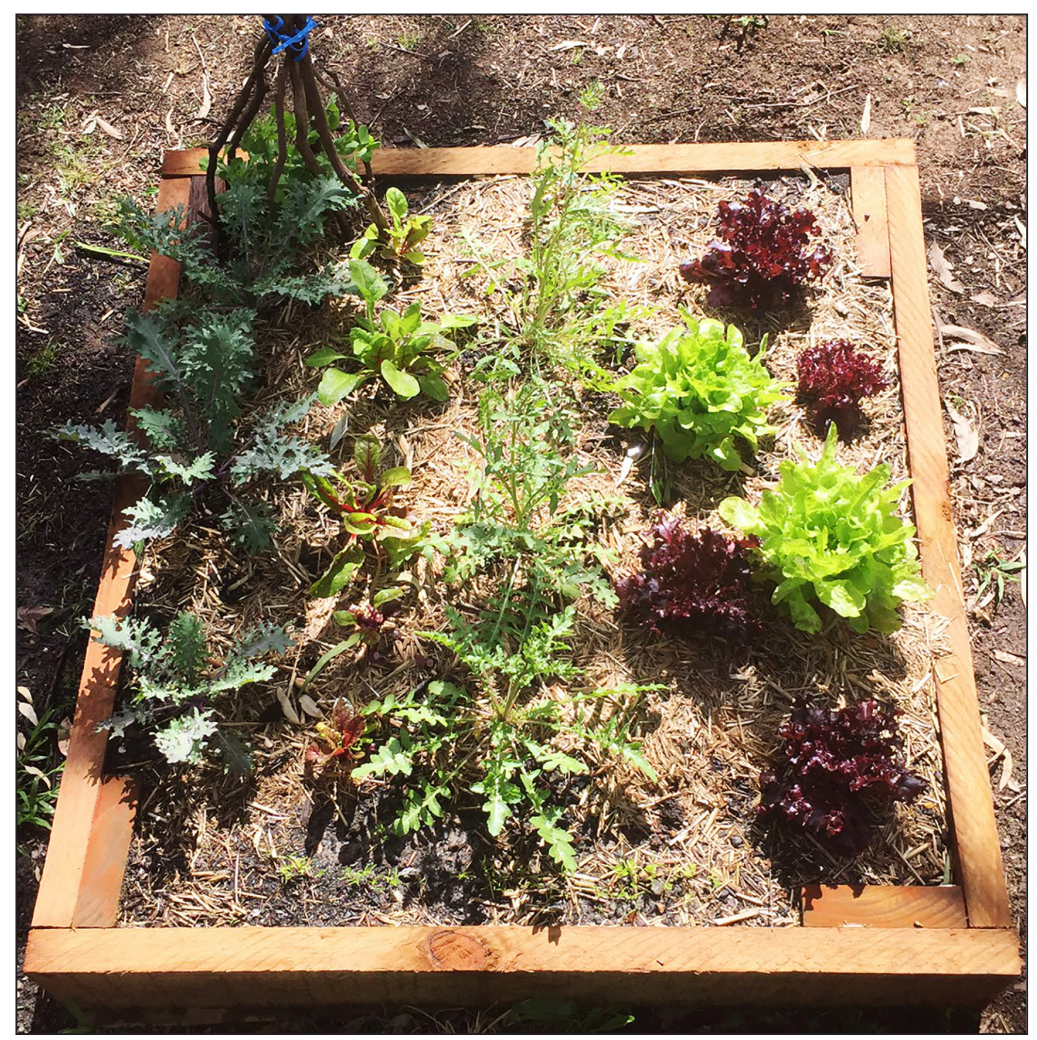

Fig. 2: Vegetable garden bed 


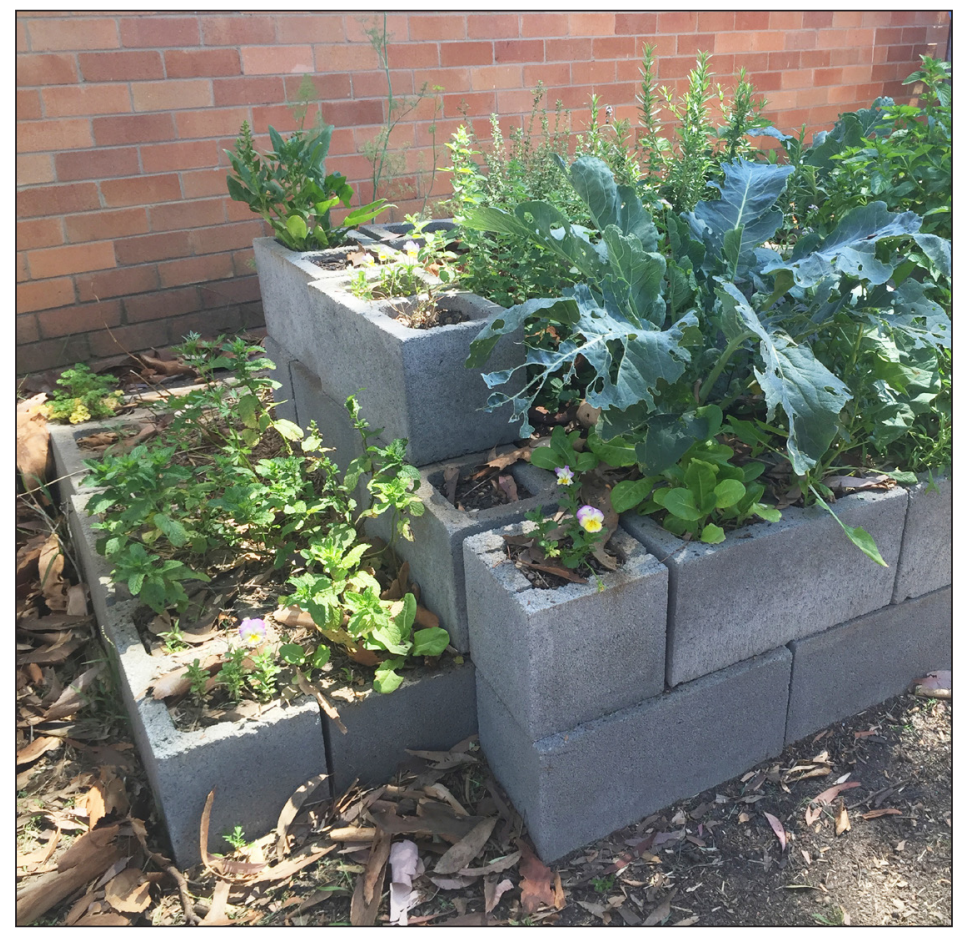

Fig. 3: Spiral herb garden

This construction process also involved decision-making and the development of specific new skills such as basic carpentry, use of power-tools, and use of gardening tools. Engagement with the multiple loose parts provided scope for engaging in higher order thinking and problem solving (Nicholson, 1974) and, in this case, collaboration. Lastly, watching their efforts materialize as semi-permanent structures with a specific purpose also seemed to have a marked effect on the students' feeling of achievement. This constructive state of engagement is the beginning of developing positive achievement patterns, which predispose students to deeper learning and support the growth of intrinsic motivation (Meece, Anderman, \& Anderman, 2006). Considering the educational content of the building, preparing, planting, and nurturing process alongside the positive psychological effects, it is not surprising that the students enjoyed the learning process, as reflected in an excerpt from one of the researcher's field notes:

The main task the kids had today was to complete the building of the spiral herb garden. This garden was begun prior to today and was about half constructed when I arrived. June seemed to be credited with a significant contribution to the 
design of the bed which was built using bessa-blocks and her ongoing input and opinion were sought by both Pete and Ray while the construction was being completed. The outside base was about $1200 \mathrm{~mm}$ square and the walls rose up and moved in a rising spiral up inside the original wall until it was about 1 metre high. June spent considerable time standing on the new levels of bessa block as each one was added and continued to stand on the walls while they were being filled with soil, an almost physical display of her ownership of the construction.

The building, planting, and tending engaged the students outside for one to two hours each morning they attended. The significance of this needs to be considered in relation to the limited experience these students had in their normal school, and out of school experiences, and the extent to which this lack of outdoor exposure has an impact on well-being, which is strongly influenced by ecology and the environment (La Placa, McNaught, \& Knight, 2013). Given that students at risk of suspension are also under considerable stress, and are often disengaged with the routines of daily schooling, the outdoor time provided during the GBL program provided numerous learning and social affordances and opportunities for just being outside in green space, which is in itself recognized as therapeutic. For example, Kaplan's (2001) Attention Restoration Theory (ART) shows that time in green space allows for restoration of undirected attention, which in turn has a rejuvenating effect on ability to control emotions and stress management mechanisms.

Indeed, the literature on stress and resilience is beginning to reflect the importance of connections with the natural world and indicate restoration from stress, lower levels of illness, higher levels of physical activity and "brainwave patterns associated with meditative calm" (Aspinall et al., 2013, cited in Chawla et al., 2014, p. 2). Peter, a GBL educator, noted the positive behaviour in the attending students:

The behaviour is always quite positive when we're working in the garden. They're very committed and focused on the different jobs at hand and I tend to find that there are very few, if any behavioural problems when we're actually working in the garden. The kids want to be there and they want to learn about these different processes. So, it's always very positive. (Peter, YCG Coordinator)

Other lenses through which the students' behaviour can be considered include Ecopsychology (Roszak, 2001), place-based education theories (Sobel, 2005), and econnection (Ward, 2017). Ecopsychology identifies the deep psychological connection between humans and the natural world and the extent to which it affects our sense of belonging and subsequently, our behaviour. Both Theodore Roszak 
(2001) and Richard Louv (2006) talk about the sense of disengagement and the need for restoring a sense of equilibrium which happens when we spend time outdoors. Place-based education speaks to the sense of place in community and personal agency and effectiveness within that community. Econnection refers our multifaceted ways of knowing and interacting with our environment. Whatever the key influences for the students in the GBL program, the change in their behaviour while at the suspension centre and their ability to manage their own responses to challenging situations was significantly affected. The following is an excerpt from an interview with the head teacher and principal who is talking about the way in which the behaviour of one of the students changed as a result of his engagement in the GBL program:

One of the big turning points for Aaron was when he was doing that work out in the driveway and shoveling and from being a little kid that lost it the first time he got frustrated, to doing this incredibly frustrating job and not losing it. ... what was different about the driveway, that seemed to be the hard job and yet, you know? He never had another turn after that. (Ray, Principal)

Reflecting on Aaron's behaviour outside the suspension centre at his regular school, Ray further noted: "Yes, he's still using it at school. I think he still realizes that, well, if I can do that driveway then I can put up with that crazy little kid that's annoying the crap out of me at school."

The students' behaviour was also amenable towards the adults attending, which included teachers, administrative staff, Community Greening staff, and researchers.

\section{Connecting to adults}

Teaching begins and ends with relationships, especially when relational models are extended beyond the four walls of the classroom into the broader community educational setting. The GBL program allowed a synergy between community educators and students to co-journey together through a variety of educational experiences. This school-community approach enabled a close rapport to be nurtured on a "level-playing field" where power struggles between adult-student were, for the most part, minimized. Peter, one of the community educators, observed:

I think one of the issues probably is that they're perhaps struggling in school and not given the opportunities in the right way for their learning styles. But I find that in the garden it's an equal playing field and they tend to thrive in that environment. (Peter, YCG Coordinator) 
By moving towards neutralizing power relationships, choice is shared amongst student and adults. Participants experienced both formal and informal relationships through community mentoring, and the school principal remarked:

Some of these kids don't get experience with functional adults ... that normal association with people coming and just hanging around, it's just really important for them. The thing I think we don't realize, is that the way we (as adults) interact with each other, they see us modeling those behaviours ... respect, familiarity, and humor and all those dynamics with a whole bunch of people who are doing different things. I think it's something we know as normal, but when you think about it for them, it's mostly not something they would even see. (Ray, Principal)

The implications of community GBL are depicted in an array of positive transformational outcomes, especially in terms of sociological dimensions. A comment made by one of the GBL educators epitomizes this view:

Maybe they haven't had the male role model and that's where we can play an important role in that respect, of just talking to them about hand tools and safety, working with things and simple things like screws, soil, and how to shovel. (Phil, RBG Community Greening Project Coordinator)

As a cohesive and collaborative community, the socio-affective impact can also be seen as intergenerational, as observed by Peter: "So he also talked about how he gardens quite regularly with his grandmother and he enjoys that aspect. It was a good opportunity ... just to have a nice conversation with him" (Peter, YCG Coordinator).

Whilst it is unrealistic to say that one GBL program is instrumental in changing students or that it is a singular solution for engagement, it certainly created observable shifts in the way students connected with adults as mentors and role models. They enjoyed conversations and social interaction when cooking on the barbeque, harvesting and preparing food together, and building the garden beds.

\section{Increased self-esteem and connection for participants}

The study has illuminated how outdoor learning can make a valuable contribution towards enhancing self-esteem, and building social capital and interpersonal skills. The students move throughout an educational system where they rarely have an opportunity to see a "final product." Due to a host of reasons, they are effectively "educational nomads" relocated from one school to the next. For this reason, many have not remained in one place long enough to witness the long-term 
impact of their learning endeavours. The GBL program became somewhat metaphorical: as the plants grew, so did the students' self-esteem. They were able to observe over time the fruits of their effort by sowing and growing the school garden. One staff member, Deanna, articulated: "They can actually see that they have achieved something. That gives them a good feeling that they have actually started something and then finished it and can see the end result" (Deanna, Teacher).

Peter offered the following observation about the ability of a garden to enhance the durability of learning:

I think back in mainstream schools they don't get the opportunity to see lots of things, projects completed either because they get distracted or they just don't have the self-belief to see it all the way to the end. ...this shows that they can persevere and they can get something accomplished. (Peter, YCG Coordinator)

In short, the OL2L program provided a myriad of benefits for disengaged students, especially in terms of enhanced self-esteem, self-efficacy, and self-concept. The school principal, Ray, remarked: "You don't need to actually reteach everything, you just need to reconnect it to something else that's effective, but you need something meaningful".

In terms of connecting in meaningful and significant ways with the GBL mentors, one student, in particular, made noticeable and incremental gains. Upon entering the OL2L centre each day, he was keen to get outside and care for the garden, watering and attending to the weeding chores. His attitude was thoroughly engaged and on task throughout the entire GBL experience, as witnessed when the RBG mentor, Phil, offered the following affirmation:

To be here, when he was probably worst outside of this, from family life, these were probably some of his best days ever at school, I would say. I don't know what his school was like, the rest of it, but he was certainly very good here and helpful and interested and asking questions. (Phil, RBG Community Greening Project Coordinator) 


\section{Discussion and Recommendations}

Our research highlights a synergy between community outreach and traditional classroom practice by working together in symbiosis. The study has demonstrated positive associations between GBL within educational landscapes and engagement of students, especially those referred to as disengaged in the school system. The interviews with the teachers reveal that the development of life skills is a prominent feature of a GBL approach. However, we were also reminded that as educators, it is important to understand where the students are coming from, particularly when working with young people who are disengaged. Peter states, "We need to remind ourselves every time we go out to different sites that many young people lack basic life skills. I've learnt not to assume that kids know all these different things." Therefore, a critical balance is required for understanding the context of students' backgrounds and everyday lives, while focusing on their strengths and potential.

Singh (2003) explains that the critique on formal education is that it has concentrated too much on instrumental and vocational skills, and on the cognitive dimension, rather than on other dimensions, such as life skills. Life skills education, on the other hand, shifts the focus towards "people's empowerment and on values and attitudes, such as promoting a better understanding between individuals, active participation and the capacity to negotiate, to live together, and to develop critical thinking" (p. 4). However, it is recognized that life skills cannot be learned in an abstract or theoretical manner. They are best taught through individual subjective experiences and everyday situations. Thus, there is impetus for a renewed focus and exploration of alternative learning environments for reengaging students within the educational system.

What became clear in the outdoor classroom is the power, agency, and criticality of relationships in GBL. Role models and mentorship, both formal and informal, were inextricably linked to the success of the study. Our findings are in accord with those of Passy (2014), who articulated gardens "provide an arena for different types of learning that complement and enrich the curriculum" (p. 28). This environment, and particularly the garden, have the potential to bridge disciplinary boundaries and foster embodied learning experiences for students towards deeper connections with self, others, and nature (Truong, 2017). Learning becomes authentic, experiential, and real, as opposed to abstract or ephemeral which often occurs within traditional classroom settings. Reflecting on these GBL outcomes, we have reconsidered Ewert's (1989) seminal work on the affordances of outdoor learning experiences as shown in Figure 4: 


\begin{tabular}{|l|l|l|l|}
\hline Psychological & Sociological & Educational & Physical \\
\hline Self-concept & Compassion & Nature awareness & Fitness \\
\hline Self-confidence & Group cooperation & Problem solving & Strength \\
\hline Self-efficacy & Respect for others & Conservation education & Coordination \\
\hline Mental acuity & Friendship & Improve academics & Balance \\
\hline Sensation seeking & Communication & Values clarification & Catharsis \\
\hline Well-being & Sense of belonging & Outdoor skills & Agility \\
\hline Stress reduction & Resilience & $\begin{array}{l}\text { Enriched cross- } \\
\text { curriculum skills }\end{array}$ & Endurance \\
\hline $\begin{array}{l}\text { Restoration and } \\
\text { rejuvenation }\end{array}$ & $\begin{array}{l}\text { Connecting and } \\
\text { relationships }\end{array}$ & Reflective skills & Gross \& fine motor skills \\
\hline
\end{tabular}

Fig. 4: Benefits of learning in outdoor environments (adapted from Ewert, 1989, p. 49).

$\mathrm{GBL}$, of course, is only one vehicle that schools and community educators can employ to reengage disengaged youth within the school setting. Notwithstanding this limitation, teachers and community mentors reported the gardens were useful for student well-being and pastoral care, in the sense that it offered a space that was considered an "educational sanctuary." The garden's calming and restorative benefits allowed reprieve from the conventional classroom and, more importantly, an educational system in which they were misaligned. GBL was particularly helpful for students who had difficulty with acting out or managing their disruptive behaviour, or who found it hard to interact with their peers in a classroom environment.

\section{Conclusion}

Individual and community transformation is fundamentally at the core of pedagogical practice. Our study exemplifies how collaboration between educational and community contexts can supplement the teaching and learning landscape. The findings have facilitated a better understanding of the processes needed to successfully support disengaged students through GBL approaches. The outdoor environment becomes a powerful teacher, in concert with strategic non-intrusive mentoring by community educators and visiting horticultural specialists in schools. The commitment of the school and educators contributed to the success of this project; however, it is recognized that this is a single case study and future research is needed to support these findings and further examine the impact of GBL approaches 
to: enhance student engagement and learning; strengthen curricular and academic outcomes; and facilitate transition from centre to school environments.

In this paper, we have articulated the value of GBL in the school curriculum, and shared how it may be implemented in a middle and secondary school setting. Our findings provide guidance to a myriad of target groups including parents, teachers, school administrators, horticulturists, key stakeholders, planners, and policy makers interested in creating more supportive environments for learning. We conclude by emphasizing that GBL can be employed by schools with limited resourcing that have staff with basic gardening skills, and, above all, an educational vision to contribute to a just society by meeting the diverse learning needs of Australia's youth.

\section{References}

Africa, J., Logan, A., Mitchell, R., et al. On Behalf of The NEI Working Group. (2014). The Natural Environments Initiative: Illustrative Review and Workshop Statement. Center for Health and the Global Environment, Harvard School of Public Health.

Aftandilian, D., \& Dart, L. (2013). Using garden-based service-learning to work toward food justice, better educate students, and strengthen campuscommunity ties. Journal of Community Engagement and Scholarship, 6(1), 55.

Astell-Burt, T., Feng, X., Mavoa, S., Badland, H. M., \& Giles-Corti, B. (2014). Do low-income neighbourhoods have the least green space? A cross-sectional study of Australia's most populous cities. BMC Public Health, 14(292), 1-11.

Barton, J., Sandercock, G., Pretty, J., \& Wood, C. (2015). The effect of playground-and nature-based playtime interventions on physical activity and self-esteem in UK school children. International Journal of Environmental Health Research, 25(2), 196-206.

Beames, S., \& Atencio, M. (2008). Building social capital through outdoor education. Journal of Adventure Education \& Outdoor Learning, $8(2), 99-112$.
Brand, D. (2001). A longitudinal study of the effects of a wilderness-enhanced program on behaviour-disordered adolescents. Australian Journal of Outdoor Education, 6(1), 40.

Brand, D., \& Smith, M. (1999). Key elements of a successful wilderness program for delinquents: A summary. Australian Journal of Outdoor Education, 4(1), 40.

Brand, D., \& Smith, M. (2000). Wilderness and delinquents: Strategies for avoiding a 'Lord of The Flies' experience. Australian Journal of Outdoor Education, 4(2), 18.

Chawla, L. (2007). Childhood experiences associated with care for the natural world: A theoretical framework for empirical results. Children, Youth and Environments, 17(4), 144-170. Retrieved from http://www. colorado.edu/journals/cye.

Chawla, L., Keena, K., Pevec, I., \& Stanley, E. (2014). Green schoolyards as havens from stress and resources for resilience in childhood and adolescence. Health \& Place, 28(0), 1-13. doi:http://dx.doi.org/10. 1016/j.healthplace.2014.03.001. 
Cheng, J. C. H., \& Monroe, M. C. (2012). Connection to nature children's affective attitude toward nature. Environment and Behavior, 44(1), 31-49.

Collado, S., Staats, H., \& Corraliza, J. A. (2013). Experiencing nature in children's summer camps: Affective, cognitive and behavioural consequences. Journal of Environmental Psychology, 33, 37-44.

Conrad, D., \& Hedin, D. (1982). The impact of experimental education on adolescent development. Child \& Youth Services, 4(3-4), 57-76.

Davies, G. (1993). On becoming human. Journal of Adventure Education and Outdoor Leadership, 9(4), 22-28.

Deci, E.L., Koestner, R., Ryan, R.M., \& Cameron. J. (2001). Extrinsic rewards and intrinsic motivation in education: Reconsidered once again. Review of Educational Research, 71(1), $1-27$.

Desmond, D., Grieshop, J., \& Subramaniam, A. (2004). Revisiting garden-based learning in basic education. International Institute for Educational Planning/Food and Agriculture Organization. Retrieved from http://www. fao.org/sd/erp/revisiting.pdf

Dickson, T., Gray, T., \& Mann, K. (2008). Australian Outdoor Adventure Activity Benefits Catalogue. Retrieved from http://outdoor council.asn.au/doc/outdooractivitybene fitscataloguefinal270808.pdf.

DiClaudio, D., Hughes, L.J., \& Savoca, L. (2013). Learning through the garden. Retrieved from http://njaes.rutgers.edu/pubs/fs1211/

Dowdell, K., Gray, T., \& Malone, K. (2011). Nature and its influence on children's outdoor play. Australian Journal of Outdoor Education, 15(2), 24-35.

Durlak, J.E., Dymnicki, A.B., Taylor, R.D., Weissberg, R.P., \& Schellinger, K.B. (2011). The impact of enhancing students' social and emotional learning: A meta-analysis of school-based universal interventions. Child Development, 82(1), 405-432.

Eisenhart, M. (1998). On the subject of interpretive reviews. Review of Educational Research, 68(4), 391-399.
Ewald, M. (1970). Salem School 1919-33: Foundation and expansion. Kurt Hahn, 22-38.

Ewert, A. (2004). The effect of outdoor experiential programs upon environment beliefs: Do they make a difference? Research in Outdoor Education, 7, 32-39.

Ewert, A. W. (1989). Outdoor adventure pursuits: Foundations, models and theories. Arizona, USA: Publishing Horizons Inc.

Fägerstam, E. (2014). High school teachers' experience of the educational potential of outdoor teaching and learning, Journal of Adventure Education and Outdoor Learning, 14(1), 56-81.

Flouri, E., Midouhas, E., \& Joshi, H. (2014). The role of urban neighbourhood green space in children's emotional and behavioural resilience. Journal of Environmental Psychology, 40, 179-186.

Fraillon, J. (2004). Measuring student wellbeing in the context of Australian schooling: Discussion paper. Retrieved from http:// www.curriculum.edu.au/verve/_resources/ Measuring_Student_Well-Being_in_the_ Context_of_Australian_Schooling.pdf

Gray, T. (1997). The impact of an extended stay outdoor education school program upon adolescent participants, Doctor of Philosophy Thesis, Faculty of Education, University of Wollongong. Retrieved from http://ro.uow. edu.au/theses/1799.

Gray, T., \& Birrell, C. (2014). Are biophilicdesigned site offices linked to high performing workers? International Journal of Environmental Research and Public Health (IJERPH) - Special Issue: Health Benefits of Nature 11, 12204-12222; doi:10.3390/ ljerph111212204. Retrieved from http:// www.mdpi.com/1660-4601/11/12/12204

Gray. T., \& Birrell, C. (2015). Touched by the Earth: A place-based outdoor learning programme incorporating the arts. Journal of Adventure Education and Outdoor Learning (JAEOL). Retrieved from http://www.tandfonline.com /doi/abs/10.1080/14729679.2015.1035293. 
Gray, T., \& Martin, P. (2012). The role and place of outdoor education in the Australian national curriculum. Australian Journal of Outdoor Education, 16(1). 39-50.

Gray, T., \& Perusco, D. (1993). Footprints in the sand - Reflecting upon the value of outdoor education in the school curriculum. Australian Council for Health, Physical Education and Recreation (ACHPER) National Journal, 40(1) 17-21.

Gray, T., \& Thomson, C. (2016). Transforming environmental awareness through the arts and place-based ecopedagogies. LEARNing Landscapes, 9(2), 239-260.

Guardino, C. A., \& Fullerton, E. (2010). Changing behaviours by changing the classroom environment. Teaching Exceptional Children, 42(6), 8-13.

Handley, R. (1998). Provoking thought, evoking meaning: Giving explanation to adventure therapy. Exploring the Boundaries of Adventure Therapy: International Perspectives, 37-45.

Harun, M. T., \& Salamuddin, N. (2014). Promoting social skills through outdoor education and assessing its effects. Asian Social Science, 10(5), 71-78.

Horwood, B. (1993). Excerpts from the Kurt Hahn address at the October 1992 AEE International Conference. Journal of Experiential Education, 16(1), 46-49.

Jackson, Y. (2002). Mentoring for delinquent children: An outcome study with young adolescent children. Journal of Youth and Adolescence, 31(2), 115-122.

Kanj, M., \& Mitic, W (2009). Working document: 7th global conference on health promotion, promoting health and development: Closing the implementation gap. Nairobi, Kenya, 26-30 October 2009 Geneva (CH): World Health Organization. Retrieved from http://www.who.int/healthpromotion/con ferences/7gchp/Track1_Inner.pdf

Kaplan, S. (2001). Meditation, restoration, and the management of mental fatigue. Environment and Behaviour, 33(4), 480-506.
Kenney, E. (2013). Forest kindergartens: The Cedarsong way. Seattle: Cedarsong Nature School.

Kesselheim, A.D. (1974). A rationale for outdoor activity as experiential education: The reasons for freezin'. Presented at The Conference on Outdoor Pursuits in Higher Education, Appalachian State University, Boone, North Carolina (USA).

Knapp, C. E. (1992). Lasting lessons: A teacher's guide to reflecting on experience. ERIC/ CRESS, Appalachia Educational Laboratory, Charleston, WV, 25325.

Korpela, K., Borodulin, K., Neuvonen, M., Paronen, O., \& Tyväinen, L. (2014). Analyzing the mediators between nature-based outdoor recreation and emotional well-being. Journal of Environmental Psychology, 37, 1-7.

Kwan, B., Frankish, J., \& Rootman, I. (2006). The development and validation of measures of "health literacy" in different populations. Vancouver: University of British Columbia Institute of Health Promotion Research \& University of Victoria Centre for Community Health Promotion Research.

La Placa, V., McNaught, A., \& Knight, A. (2013). Discourse on wellbeing in research and practice. International Journal of Wellbeing, 3(1), 116-125. doi:10.5502/ijw.v3i1.7.

Louv, R. (2006). Last child in the woods: Saving our children from nature deficit disorder. Chapel Hill, NC: Algonquin Books Of Chapel Hill.

McCurdy, L. E., Winterbottom, K. E., Mehta, S. S., \& Roberts, J. R. (2010). Using nature and outdoor activity to improve children's health. Current Problems in Pediatric and Adolescent Health Care, 40(5), 102-117.

McLoughlin, C., \& Clarke, B. (2010). Relational matters: A review of the impact of school experience on the mental health in early adolescence. Educational \& Child Psychology, 27(1), 91-103.

Meece, J. L., Anderman, E. M., \& Anderman, L. H. (2006). Classroom goal structure, student motivation and academic achievement. Annual Review of Psychology, 57, 487-503. 
New South Wales Department of Education and Communities. (2015). The wellbeing framework for schools. Retrieved from https://www.det.nsw.edu.au/wellbeing/ about/16531_Wellbeing-Framework-forschools_Acessible.pdf

Nicholson, S. (1974). How not to cheat children: The theory of loose parts. In G. Coates (Ed.), Alternate learning environments. Stroudsberg, PA: Dowden, Hutchison and Ross.

Noddings, N. (1988). Schools face crisis in caring. Education Week, 8(14), 32.

Okely, T., \& Gray, T. (1997). The effect of an extended stay outdoor education program on the aerobic fitness of adolescent boys. In Gray, T. \& Hayllar, B. [Eds]. (1997). Catalysts for Change: The 10th National Outdoor Education Conference Proceedings (pp. 206210). Collaroy Beach, NSW. January 20-24.

Passy, R. (2014). School gardens: teaching and learning outside the front door, Education 3-13: International Journal of Primary, Elementary and Early Years Education, 42(1), 23-38. doi:10.1080/03004279.2011.636371

Passy, R., Morris, M., \& Reed, F. (2010). Impact of school gardening on learning: Final report submitted to the Royal Horticultural Society. Retrieved from http://apps.rhs.org.uk/ schoolgardening/uploads/documents/ Impact_of_school_gardening_on_learning_821.pdf

Propst, D. B., \& Koesler, R. A. (1998). Bandura goes outdoors: Role of self-efficacy in the outdoor leadership development process. Leisure Sciences, 20(4), 319-344.

Quay, J. (2015). Understanding life in school: From the academic classroom to outdoor education. Basingstoke, Hampshire: Palgrave Macmillan.

Rhodes, J. E., Grossman, J. B., \& Resch, N. L. (2000). Agents of change: Pathways through which mentoring relationships influence adolescents' academic adjustment. Child Development, 71(6), 1662-1671.

Roffey, S. (2016). Building a case for whole-child, whole-school wellbeing in challenging contexts. Educational \& Child Psychology, 33(2), 30-42.
Rohrs, H. (1970). The educational thought of Kurt Hahn. London: Routledge \& Kegan Paul Ltd.

Roszak, T. (2001). The voice of the Earth: An exploration of ecopyschology (2nd ed.). Grand Rapids, MI: Phanes Press Inc.

Ruiz-Gallardo, J. R., Verde, A., \& Valdés, A. (2013). Garden-based learning: An experience with "at risk" secondary education students. The Journal of Environmental Education, 44(4), 252-270.

Ryan, D., \& Gray, T. (1993). Integrating outdoor education into the school curriculum - A case study. International Council for Health, Physical Education and Recreation, Vol XXIX, No 2, 6-13.

Scott, G., Boyd, M., \& Colquhoun, D. (2013). Changing spaces, changing relationships: The positive impact of learning out of doors. Australian Journal of Outdoor Education, 17(1), 47-53.

Selhub, E., \& Logan, A. (2012). Your brain on nature: The science of nature's influence on your health, happiness and vitality. Somerset: Wiley.

Sharma-Brymer, V., \& Bland, D. (2016). Bringing nature to schools to promote children's physical activity. Sports Medicine, 1-8.

Singh, M. (2003). Understanding life skills. Hamburg: UNESCO Institute for Education.

Sobel, D.. (2005). Place-based education: Connecting classrooms and communities. Great Barring, MA: The Orion Society.

Taylor, A. F., \& Kuo, F. E. (2009). Children with attention deficits concentrate better after walk in the park. Journal of Attention Disorders, 12(5), 402-409.

Taylor, A. F., Kuo, F. E., \& Sullivan, W. C. (2002). Views of nature and self-discipline: Evidence from inner city children. Journal of Environmental Psychology, 22(1), 49-63.

Truong, S. (2009, January 1). Outdoor learning. In J. Vallentyne (Ed.), Ever Active Kids Manual (pp. 117-120). Edmonton, Alberta: Alberta Fitness Leadership Certification Association. 
Truong, S. (2017). Expanding curriculum pathways between education for sustainability and health and physical education. In K. Malone., S. Truong, \& T. Gray (Eds.), Reimagining sustainability in precarious times (pp. 239-252). Singapore: Springer.

Truong, S., \& Mahon, M. (2012). Through the lens of participatory photography: Engaging Thai children in research about their community play centre, International Journal of Play, 1(1), 75-90. doi:10.1080/21594937.201 2.658647

UNICEF. (2003). Life skills: Definition of terms. Retrieved from http://www.Unicef.Org/ Lifeskills/Index_7308.html

Ward, K. (2017). Beyond sustainability - Visions of post-humanist e-connection in early childhood education. In K. Malone., S. Truong, \& T. Gray (Eds.), Reimagining sustainability in precarious times (pp. 129-143). Singapore: Springer.
Weed, M. (2005). "Meta interpretation": A method for the interpretative synthesis of qualitative research. Forum. Qualitative Social/ Research, 6(1), Art. 3 7. Retrieved from http//nbn-resolving.de/urn:nbn:de: 0114-fqs 0501375

Wilson, E. (2015). E.O. Wilson explains why parks and nature are really good for your brain. The Washington Post. Retrieved from http://Www.Childrenandnature.Org/2015 /10/01/E-O-Wilson-Explains-Why-ParksAnd-Nature-Are-Really-Good-For-YourBrain/

Yeh, H.P., Stone, J.A., Churchill, S.M., Wheat, J.S., Brymer, E., \& Davids, K. (2015). Physical, psychological and emotional benefits of green physical activity: An ecological dynamics perspective. Sports Medicine. 1-7.

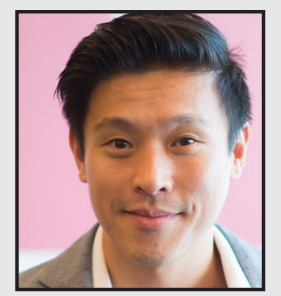

Son Truong, PhD (University of Alberta) is a Lecturer in Health and Physical Education Curriculum and Pedagogy, and a member of the Centre for Educational Research, at Western Sydney University. He is an award-winning educator with diverse experience working with young people in majority and minority world contexts. Son has presented and published in the area of play, well-being, outdoor and environmental education, and international service-learning in higher education. His forthcoming publication is a co-edited research volume, Reimagining Sustainability in Precarious Times (2017), which explores new perspectives for sustainability and education in the context of the Anthropocene. 


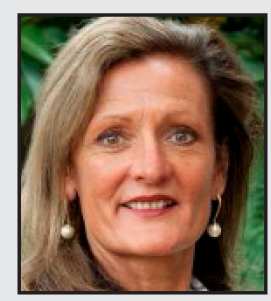

Tonia Gray (PhD) is a Senior Researcher in the Centre for Educational Research at Western Sydney University. With over 30 years in Outdoor Education, Associate Professor Gray is a multi-award-winning pedagogue; most recently receiving an Australian Award for University Teaching for excellence in outdoor experiential education. Her research explores human-nature relationships and their impact on well-being and human development. Tonia's forthcoming publications include: the International Handbook of Women in Outdoor Learning (2017); a co-edited research volume, Reimagining Sustainability in Precarious Times (2017); and The Globalisation of Higher Education: Developing Internationalised Education in Research and Practice (2017).

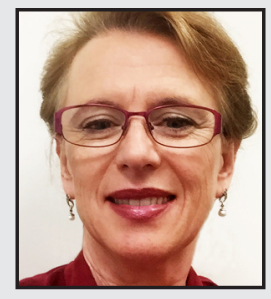

Kumara Ward was awarded her PhD from Western Sydney University where she lectures in the School of Education and is a member of the Centre for Educational Research. Specializing in Creative Pedagogies, and a qualified Nature School educator, her key teaching/research interests are reinvigorating sustainability education through creative cross curricula experiences in the outdoors and in the classroom. Kumara's forthcoming publication will appear in the Palgrave International Handbook of Women and Outdoor Learning (2017), with a chapter entitled "Singing in the Forest: Outdoor Education as Early Childhood Curriculum." 